Research article

\title{
Plant invasions, restoration, and economics: Perspectives from South African fynbos
}

\author{
Mirijam Gaertner $^{\mathrm{a}}$, Henning Nottebrock ${ }^{\mathrm{b}}$, Helanya Fourie ${ }^{\mathrm{c}}$, Sean D.J. Privett ${ }^{\mathrm{d}}$, David M. Richardson ${ }^{\mathrm{a}, *}$ \\ a Centre for Invasion Biology, Department of Botany and Zoology, Stellenbosch University, Private Bag X1, Matieland 7602, South Africa \\ ${ }^{\mathrm{b}}$ Potsdam University, Plant Ecology and Nature Conservation, Maulbeerallee 3, 14469 Potsdam, Germany \\ c Western Cape Department of Agriculture, Private Bag X1, Elsenburg 7607, South Africa \\ d Fynbos Ecoscapes, Witkrans, Gansbaai 7220, South Africa
}

\section{A R T I C L E I N F O}

\section{Article history:}

Received 13 March 2012

Received in revised form 3 May 2012

Accepted 8 May 2012

\section{Keywords:}

Biological invasions

Cost-benefit analysis

Degradation

Exotic species

Flower harvesting

Rehabilitation

\begin{abstract}
A B S T R A C T
Restoration is gaining importance in the management of plant invasions. As the success of restoration projects is frequently determined by factors other than ecological ones, we explored the ecological and financial feasibility of active restoration on three different invaded sites in South Africa's Cape Floristic Region. The aim of our study was to identify cost-effective ways of restoring functional native ecosystems following invasion by alien plants. Over three years we evaluated different restoration approaches using field trials and experimental manipulations (i.e. mechanical clearing, burning, different soil restoration techniques and sowing of native species) to reduce elevated soil nutrient levels and to re-establish native fynbos communities. Furthermore we investigated the possibility of introducing native fynbos species that can be used for sustainable harvesting to create an incentive for restoration on private land.

Diversity and evenness of native plant species increased significantly after restoration at all three sites, whereas cover of alien plants decreased significantly, confirming that active restoration was successful. However, sowing of native fynbos species had no significant effect on native cover, species richness, diversity or evenness in the Acacia thicket and Kikuyu field, implying that the ecosystem was sufficiently resilient to allow autogenic recovery following clearing and burning of the invasive species. Soil restoration treatments resulted in an increase of available nitrogen in the Acacia thicket, but had no significant effects in the Eucalyptus plantation. However, despite elevated available soil nitrogen levels, native species germinated irrespective whether sown or unsown (i.e. regeneration from the soil seed bank).

Without active introduction of native species, native grasses, forbs and other shrubs would have dominated, and proteoids and ericoids (the major fynbos growth forms) would have been under-represented.

The financial analysis shows that income from flower harvesting following active restoration consistently outweighs income following passive restoration, but that the associated increase in income does not always justify the higher costs. We conclude that active restoration can be effective and financially feasible when compared to passive restoration, depending on the density of invasion. Active restoration of densely invaded sites may therefore only be justifiable if the target area is in a region of high conservation priority.
\end{abstract}

(c) 2012 Elsevier GmbH. All rights reserved.

\section{Introduction}

Management of ecosystems invaded by alien plants is an increasingly complex problem worldwide (e.g. Roura-Pascual et al., 2009). Most restoration programs use passive approaches for restoring aspects of functionality in degraded ecosystems by seeking to enhance the recovery of native species by simply removing existing invasive species (Le Maitre et al., 2011; Gaertner et al.,

\footnotetext{
* Corresponding author. Fax: +27 218082995

E-mail address: rich@sun.ac.za (D.M. Richardson).
}

2012). This approach often fails due to secondary invasions of the same invader or other invasive species (Zavaleta et al., 2001; Loo et al., 2009), resource alterations caused by the invasive species and/or management interventions (Galatowitsch and Richardson, 2005; Buckley, 2008; Vince, 2011), or 'legacy effects' - long-lasting changes in ecosystem structure such as increased soil nutrient levels that persist following the removal of the invader (D'Antonio and Meyerson, 2002; Marchante et al., 2009). The result is that many control efforts have only ephemeral benefits and tenuous long-term value (Le Maitre et al., 2011). Consequently, it has been argued that active restoration (i.e. additional restoration activities beyond removal of the invader) is vital when dealing with alien 
invasions (Esler et al., 2008; Reid et al., 2009). Active restoration has in many cases proven successful in controlling invasive species and promoting native species (e.g. Bakker and Wilson, 2004; Cox and Allen, 2008), but the high cost of restoration interventions is an important constraint. The question of whether and how to pay for restoration has been widely discussed in the scientific literature (Holl and Howarth, 2000; Milton et al., 2003; Benayas et al., 2009). Although these considerations are important for initiating projects (Goldstein et al., 2008), very few restoration studies have directly considered financial incentives (Aronson et al., 2010). A key question is: When is it ecologically necessary and financially justifiable to implement restoration activities that extend beyond the removal of alien invaders? This question can be addressed from three different angles.

Firstly, it is important to evaluate the added benefits of active restoration activities in, for example, enhancing biodiversity and restoring desired functionality to ecosystems. Secondly, the financial costs of restoration must be considered. Thirdly, potential financial incentives for restoration of private land after alien invasion need to be explored. To investigate the ecological feasibility of active restoration after alien plant invasion we tested a range of management strategies through field trials and experimental manipulations on three degraded sites on the Agulhas Plain, South Africa, which are representative for many areas in the region. The sites were an old field dominated by the alien grass Pennisetum clandestinum Pers. (Kikuyu), an abandoned Eucalyptus plantation, and a fynbos community invaded by nitrogen-fixing Australian Acacia species. To investigate the financial feasibility of active restoration we tested the possibility of introducing native species that can be used for sustainable flower harvesting to create incentives for landowners.

Our study was conducted in a fynbos ecosystem on the Agulhas Plain in South Africa's Western Cape Province. Alien plant invasions are a major threat to biodiversity in this region (Rouget et al., 2003). Large tracts of natural vegetation have been transformed by invasive alien tree, shrub and grass species, reducing biodiversity and causing various profound ecosystem-level changes (e.g. changes in nutrient cycling or disturbance regimes) (Richardson and Van Wilgen, 2004). Extensive clearing operations are underway throughout the region, but removing the invaders is often not sufficient to re-establish a functional native ecosystem (Esler et al., 2008). A major problem for restoration is that the invaders are fast growing, competitive species, many of which produce large, longlived seed banks that facilitate persistence (Wilson et al., 2011). Elevated soil nutrient levels caused by the invaders are another challenge for restoration.

Many invasive plants accumulate nitrogen $(\mathrm{N})$ through increased biomass and net primary production, i.e. through production of litter with higher decomposition rates than native species (Ehrenfeld, 2003). Soil enrichment can persist long after the removal of the invader, and this may ameliorate the conditions for invasive alien plants (Vinton and Goergen, 2006) but retard the recovery of native communities (Lindsay and French, 2005; Marchante et al., 2009; Gaertner et al., 2011).

Active restoration interventions include: the sowing of native species to re-establish a functional native community and increase biodiversity, and soil restoration treatments to reduce soil nutrient levels. Sowing of native species has yielded mixed results. Sowing of native species greatly improved structure and composition of the vegetation after invasion by pines in mountain fynbos vegetation (Holmes, 2001) but prevented seedling recruitment in a native shrub ecosystem (renosterveld) (Ruwanza, 2009). Techniques for reducing elevated soil nutrient levels include repeated burning (Stock and Lewis, 1986) and addition of carbon to the soil (Prober et al., 2005; Blumenthal et al., 2003). Carbon supplements are known to enhance the activity of carbon-limited decomposing soil micro-organisms that subsequently compete with plants for available soil nitrogen $\left(\mathrm{NH}_{4}{ }^{+}\right.$and $\mathrm{NO}_{3}{ }^{-}$) (Perry et al., 2010) and have in some cases been shown to successfully immobilize soil nitrogen and limit growth of nitrophilic plant species (e.g. Morghan and Seastedt, 1999; Blumenthal et al., 2003; Prober et al., 2005). Carbon addition has been widely used in the Northern Hemisphere, especially in North American grasslands (Blumenthal et al., 2003; Suding et al., 2004), but the technique has been little used in South Africa (but see Holmes, 2008).

We investigated restoration interventions following invasion by nitrogen-fixing Australian Acacia spp., Australian Eucalyptus spp. and the East African grass invader P. clandestinum Pers. (Kikuyu). Acacia invasions can have major biotic consequences (i.e. altered native species composition, reduced native species richness, and depleted native soil seed banks (Musil, 1993; Holmes and Cowling, 1997; Holmes, 2002; Gaertner et al., 2011)) and abiotic consequences (i.e. altered nutrient cycling through nitrogen fixation and increased litter production (Musil, 1993; Yelenik et al., 2004; Gaertner et al., 2011; Le Maitre et al., 2011)). Control of these species is especially difficult because of their strong persistence due to their capacity to produce large, long-lived seed banks (Richardson and Kluge, 2008). Australian Eucalyptus species have been planted extensively for timber production in South Africa and some species are important invaders (Forsyth et al., 2004; Henderson, 2007). Stands of eucalypts impact on biodiversity by reducing native species richness and by changing soil nutrient properties (Gaertner et al., 2011). P. clandestinum has been planted widely in the region and is rapidly invading disturbed areas (Gaertner et al., 2011). This species is especially problematic in old agricultural fields where it can limit regeneration of native species by forming impenetrable mats (Posada et al., 2000).

We explored the possibility of introducing fynbos species that can be used for sustainable flower harvesting as a financial incentive for restoration. The Western Cape is a key producer of fynbos for the export market, with the majority of flowers exported to Europe (TradeMap, 2012). Within the Western Cape the Agulhas Plain is thought to have higher flower harvesting levels and generate more income than any other fynbos area (Heydenrych, 1999). While some producers cultivate fynbos species in managed orchards, many wildflowers are regularly harvested from natural populations (Conradie and Knoesen, 2009).

The financial benefit to restoring lands with wildflower species on the Agulhas Plain could therefore be substantial enough to motivate individual land owners to incorporate restoration into their land management. As the Agulhas Plain is part of the Cape Floristic Region, a global biodiversity hotspot, a sustainable supply of fynbos biodiversity has value beyond the price received in the flower market. Based on this public biodiversity value, the argument can be made that clearing operations should be subsidized.

The overall aim of our study was to identify cost-effective ways of restoring functional native ecosystems following alien invasion. Specific objectives of the study were (1) to test active restoration interventions to reduce elevated soil nutrient levels and to re-establish a native fynbos community and (2) to investigate the possibility of introducing native fynbos species that can be used for sustainable harvesting to create an incentive for restoration on private land.

\section{Methods}

\section{Site description}

The study was conducted on the Agulhas Plain in South Africa's Cape Floristic Region (CFR) where the predominant vegetation type 


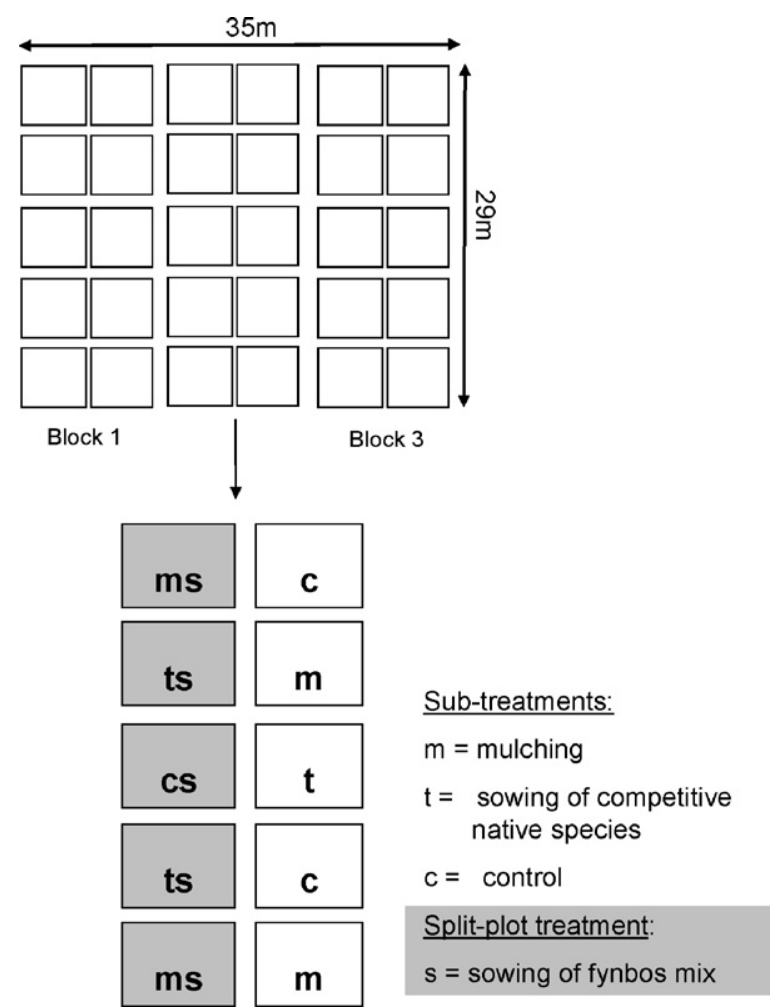

Fig. 1. Split-plot replicated block design for restoration strategies for the restoration of alien-invaded sites on Flower Valley Farm, Western Cape, South Africa. Plots measure $5 \mathrm{~m} \times 5 \mathrm{~m}$ with $1 \mathrm{~m}$ buffer strips between plots and blocks.

is fynbos, a sclerophyllous shrubland on nutrient-poor substrata. The Mediterranean-type climate is characterized by cool, wet winters and hot, dry summers. The three study sites were situated on Flower Valley Farm near Gansbaai, about $175 \mathrm{~km}$ east of Cape Town. The vegetation on Flower Valley Farm is classified as Overberg Sandstone Fynbos (Rebelo et al., 2006) with a small patch of Afrotemperate Forest (further details in Gaertner et al., 2011).

We investigated three invaded sites: a former Eucalyptus plantation, an Acacia thicket and an old agricultural field (henceforth the "Kikuyu field") invaded by P. clandestinum. Eucalyptus trees were planted in the 1940 s for timber production on a previously disturbed site. The Eucalyptus plantation measured $11,200 \mathrm{~m}^{2}$ and formed a heterogeneous mixture of E. conferruminata D.J. Carr. and S.G.M. Carr., E. cladocalyx F. Muell. and E. gomphocephala A.D.C., interspersed with some Acacia saligna Cunn. ex. G. Don and Paraserianthes lophantha (Willd.) I.C. Nielson (locality: S34 $32^{\prime \prime} 53.88^{\prime}$; E19 $27^{\prime \prime} 41.17^{\prime}$ ). The Acacia site was invaded in the last $15-20$ years; it measured $4950 \mathrm{~m}^{2}$ and was not disturbed prior to invasion (locality: S34 33"16.41'; E19 $27^{\prime \prime} 38.95^{\prime}$ ). The Kikuyu field (locality: $\mathrm{S} 34^{\circ} 32^{\prime \prime} 46.59^{\prime}$; E19 $28^{\prime \prime} 16.98^{\prime}$ ) was $840 \mathrm{~m}^{2}$ in size and was a potato field until the mid 1980s. Prior to potato planting the fynbos was removed through deep ploughing.

\section{Restoration experiments}

We adopted a split-plot replicated block design with sowing of native species as a split-plot treatment (from here-on referred to as sowing) and herbicide, mulching and sowing of selected native species applied as the sub-treatment (from here-on referred to as sub-treatments). On each of the three sites we established three blocks $(11 \mathrm{~m} \times 29 \mathrm{~m})$ with ten $5 \mathrm{~m} \times 5 \mathrm{~m}$ plots per block with $1-\mathrm{m}$ buffer strips among plots and blocks (Fig. 1). The Acacia thicket and Eucalyptus plantation were cleared in summer (January and
February) 2008 (debris was not removed). In the Kikuyu field we applied the grass-specific herbicide "Focus-Ultra" (active ingredient cycloxydim) to foliage at a rate of $4 \mathrm{~L} / \mathrm{ha}$ at $2 \%$ concentration by knapsack sprayer. As fynbos is a fire-prone vegetation type we used burning as an initial restoration method; all three sites were burned in March 2008. In April 2008 we started active restoration. We chose April for our restoration experiment as most of the fynbos species germinate in autumn at the start of the rainy season. Restoration treatments are summarized in Table 1.

\section{Sub-treatments (mulching, sowing and herbicide application)}

Sub-treatments were applied at random to plots within each of the three blocks $(n=5)$. In the Acacia thicket and the Eucalyptus plantation sawdust $(49.8 \% \mathrm{C}$ and $0.39 \% \mathrm{~N}$ ) was applied in April 2008 at a rate of $30 \mathrm{~kg}$ per plot $\left(0.6 \mathrm{~kg} \mathrm{C} / \mathrm{m}^{2}\right)$. As second subtreatment Pelargonium capitatum L. L'Hér, a fast-growing native species, which might have the capacity to compete with invaders for soil nutrients, was sown at $500 \mathrm{~g}$ per plot. In the kikuyu field the systemic herbicide "Focus-Ultra", was applied to foliage at a rate of $4 \mathrm{~L} /$ ha at $2 \%$ concentration by knapsack sprayer in September 2008 , 2009 and 2010.

Additionally Leucadendron coniferum L. Meisn. and Chrysanthemoides monilifera L. T. Nord, competitive native shrubs which might have the potential to out-shade Kikuyu, were sown.

\section{Seed collecting and sowing (split-plot treatment)}

For the split-plot treatment we selected fast growing competitive native species that produce high quantities of easy harvestable seeds and that germinate easily. Furthermore we selected species that can be utilized for sustainable harvesting. The selected species were: Helichrysum crispum L. D. Don, Lessertia frutescens DC, $L$. coniferum L. Meisn., Otholobium fruticans L. C.H. Stirt., Searsia laevigata L. F.A. Barkley var. laevigata, and Stoebe plumosa L.

Seed collection began in October 2007 and continued throughout the summer and early autumn (March 2008). All seeds were collected in natural communities on Flower Valley Farm to avoid genetic contamination. Seed was collected by hand only when ripe (i.e. ready to disperse or drop from the plant) and was stored in porous paper bags in a dry room after sprinkling with Karbadust insecticide powder to kill potential seed predators. As pre-treatments (to break dormancy and accelerate germination) we applied smoking and soaking in hot water, respectively depending on the species requirements. Seed was broadcast sown and immediately raked lightly into the soil to ensure good seed-soil contact (for details on pre-treatment for each species and seed quantity, see supplementary material S1).

\section{Monitoring}

\section{Vegetation surveys}

We conducted vegetation surveys over three years: (1) three months after the restoration (in July 2008) we recorded total projected plant cover, open soil and abundance for each growth form in $25 \mathrm{~m}^{2}$ and additionally in $1 \mathrm{~m}^{2}$ plots in the centre of each $25 \mathrm{~m}^{2}$ plot. We distinguished between the following growth forms: native graminoids, geophytes, forbs and succulents, and native woody species including ericoids, proteoids, other shrubs (all native shrubs excluding Ericaceae and Proteaceae) and alien graminoids and trees; (2) ten months after the restoration (in February 2009) we repeated the survey, but then also recorded abundance as percentage projected canopy cover for each species in the $1 \mathrm{~m}^{2}$ and the $25 \mathrm{~m}^{2}$ plots. Finally, two years after the restoration (in April 2010) we recorded abundance as percentage projected canopy cover for each species only in the $25 \mathrm{~m}^{2}$ plots. 
Table 1

Restoration activities conducted on a Kikuyu field, Acacia thicket and Eucalyptus plantation plots ( $5 \mathrm{~m} \times 5 \mathrm{~m}$ ) on Flower Valley Farm, Western Cape, South Africa.

\begin{tabular}{|c|c|c|c|}
\hline Restoration treatments & Kikuyu field & Acacia thicket & Eucalyptus plantation \\
\hline split-plot treatment (April 2008) & $\begin{array}{l}\text { native species mix: sowing of } \\
\text { competitive native species that can } \\
\text { be used for sustainable harvesting }\end{array}$ & $\begin{array}{l}\text { native species mix: sowing of } \\
\text { competitive native species that can } \\
\text { be used for sustainable harvesting }\end{array}$ & $\begin{array}{l}\text { native species mix: sowing of } \\
\text { competitive native species that can } \\
\text { be used for sustainable harvesting }\end{array}$ \\
\hline \multirow[t]{4}{*}{ sub-treatments (April 2008) } & $\begin{array}{l}\text { herbicide application: systemic } \\
\text { herbicide "Focus-Ultra", } 0.41 / \text { ha at } 2 \% \\
\text { concentration by knapsack sprayer }\end{array}$ & $\begin{array}{l}\text { mulching: sawdust at a rate of } \\
30 \mathrm{~kg} / \mathrm{plot}\end{array}$ & $\begin{array}{l}\text { mulching: sawdust at a rate of } \\
30 \mathrm{~kg} / \mathrm{plot}\end{array}$ \\
\hline & competitive native species: & competitive native species: & competitive native species: \\
\hline & $\begin{array}{l}\text { Leucadendron coniferum and } \\
\text { Chrysanthemoides monilifera which } \\
\text { might have the potential to } \\
\text { out-shade Kikuyu }\end{array}$ & $\begin{array}{l}\text { Pelargonium capitatum L. L'Hér which } \\
\text { has the capacity to compete with } \\
\text { invaders for soil nutrients }\end{array}$ & $\begin{array}{l}\text { Pelargonium capitatum L. L'Hér which } \\
\text { has the capacity to compete with } \\
\text { invaders for soil nutrients }\end{array}$ \\
\hline & $\begin{array}{l}\text { control: clearing of invasive species } \\
\text { and burning, without any further } \\
\text { treatment except for follow-up } \\
\text { herbicide applications }\end{array}$ & $\begin{array}{l}\text { control: clearing of invasive species } \\
\text { and burning, without any further } \\
\text { treatment except for follow-up } \\
\text { herbicide applications }\end{array}$ & $\begin{array}{l}\text { control: clearing of invasive species } \\
\text { and burning, without any further } \\
\text { treatment except for follow-up } \\
\text { herbicide applications }\end{array}$ \\
\hline $\begin{array}{l}\text { follow-up treatments (spring 2008; } \\
2009 \text { and 2010) }\end{array}$ & $\begin{array}{l}\text { follow-up: herbicide application } \\
\text { (systemic herbicide "Focus-Ultra", } \\
4 \mathrm{~L} / \text { ha at } 2 \% \text { concentration by } \\
\text { knapsack sprayer) }\end{array}$ & $\begin{array}{l}\text { follow-up: herbicide spot treatment } \\
\text { on re-sprouting invasives (systemic } \\
\text { herbicide “Garlon”, } 4 \text { L / ha at } 2 \% \\
\text { concentration by knapsack sprayer) }\end{array}$ & $\begin{array}{l}\text { follow-up: herbicide spot treatment } \\
\text { on re-sprouting invasives (systemic } \\
\text { herbicide "Garlon". } 4 \text { L / ha at } 2 \% \\
\text { concentration by knapsack sprayer) }\end{array}$ \\
\hline
\end{tabular}

\section{Soil surveys}

To monitor success of the soil restoration we sampled soil before restoration (August 2007 and February 2008) and after restoration (August 2008) and analysed it for total nitrogen (N). Soil samples were taken randomly with a $10-\mathrm{cm}$ deep and 5 -cm diameter soil core in each subplot in all three sites $(n=90)$. Each soil sample comprised five cores which were combined in a bulk sample. Analysis for total nitrogen was done by a commercial laboratory (Bemlab Pty Ltd., Somerset West) using total combustion analysis. We also recorded resin-available nitrogen $\left(\mathrm{NH}_{4}{ }^{+}\right.$and $\left.\mathrm{NO}_{3}{ }^{-}\right)$using resin bags in the spring and summer before restoration (October 2007 and February 2008) and spring after restoration (November 2008) (Gaertner et al., 2011).

\section{Statistical analysis}

We used linear mixed-effects models (LME, package nlme, Pinheiro et al., 2007) in R 2.14.1 (R Development Core Team, 2011) to determine the outcomes of our active restoration. We analysed changes in soil properties (i.e. total and available nitrogen) and vegetation parameters (alien cover, native cover, species richness and growth forms (proteoids and ericoids)) over time. In addition to species richness and native cover we calculated diversity and evenness (using Shannon-Wiener diversity index) in Estimate SWin 800. All response variables were described with effects of active restoration including split-plot treatment (sowing), subtreatments (i.e. mulching, sowing of selected native species and herbicide application) and year (2007, 2008, 2009 and 2010). Data on species richness was recorded in 2007 and three years after the restoration (in 2010) when species could be identified up to species level. Therefore species richness, diversity and evenness are shown for 2007 and 2010, only. Models for soil properties include samples from October 2007 (August for total N), February 2008 and November 2008 (August for total N). Data were arcsine-square-root transformed or log-transformed to ensure normal distribution. We tested for interactions among explanatory variables and applied spatial and temporal random effects of block and time that account for environmental and temporal variation between sites and avoids pseudo-replication (Venables and Ripley, 2002). For all models we removed non-significant model terms $(p>0.05)$ in a stepwise backward manner to obtain a minimal adequate model for each response variable (Crawley, 2007). We determined similarity in species composition using Bray-Curtis similarity index and nonmetrical multidimensional scaling (NMDS) in Primer (version 5).
We used absolute numbers (total species cover), which is the most commonly used method for multivariate similarity analysis.

Before calculation of Bray-Curtis similarity data were transformed (Clarke and Warwick, 2001). NMDS was performed running 50 iterations (restarts) with a minimum stress value of 0.01 . Similarity percentages analysis (SIMPER) was used to identify species contributing strongly to within group similarities, as well as dissimilarities among different treatments.

To investigate whether active restoration can be economically feasible we analysed the effects of our restoration on species of the growth forms 'proteoids' and 'ericoids' as these species are widely used for sustainable harvesting.

\section{Financial analysis}

To investigate the potential for introducing native fynbos species that can be used for sustainable harvesting we compared costs and income of our active restoration to the cost and income of passive restoration (clearing and burning only). Passive restoration costs are those associated with clearing (including initial clearing and follow-up operations) and prescribed burning only, whereas active restoration incurs additional costs for mulching, seed collection and sowing.

Varying between the type and density of invasive species, the clearing costs of the experimental study ranged from 6000 ZAR to 25,000 ZAR per ha (Bailey 2009, personal communication). Due to the small scale at which the restoration experiments were conducted, extrapolation to a larger area would have resulted in an overestimation of costs and would not have accurately reflected the clearing costs that landowners could expect. Consequently, clearing costs from the Working for Water programme (Marais and Wannenburgh, 2008) were used as an indication of the total cost of clearing low ( $\leq 5 \%)$ and high density ( $\geq 75 \%)$ of Acacia and Eucalyptus invasions.

The cost of controlling Kikuyu was based on an estimate of herbicide application (including labour cost) per ha. It was assumed that a farmer uses his own tractor and implements. Tractor and implement costs include fuel, repair and maintenance costs and are estimated according to the Guide to Machinery Costs (2011). Labour costs were estimated according to a market related wage rate of 7 ZAR per h for farm workers.

We estimated and compared the income that can be derived from proteoid and ericoid species in actively and passively restored sites, over a 20 -year period. We used species abundances derived 
from the vegetation survey in 2010 as basis for the analysis. Income was estimated as the product of the average number of stems per plant per year (Bailey et al., 2008), the market price per stem, and abundance after restoration as averaged across the results of the restoration experiment. To project income growth over 20 years we used a quality factor and growth rate for harvestable stems per year post-fire vegetation age as derived from a regional resource base assessment: ericoids exhibit a consistent annual increase in the total number of stems, while proteoids exhibit peak production between year six to ten, after which production steadily declines (Bailey et al., 2008). The quality of stems peak in years 11 and 12, and then decline to the extent that in year 20 only $30 \%$ of stems are acceptable for the market. Finally, we assumed that, in line with the prescriptions of sustainable harvesting only $50 \%$ of these stems are harvested (Scott et al., 2004).

We used net present value (NPV) as a decision criterion to compare between different project outcomes, incorporating a discount factor to accommodate for the diminishing value of future benefits. Future cash flows were discounted based on the principle that income received today is preferred to income received in the future, while the opposite holds true for costs.

A positive NPV indicated a net profit and was seen as a financial argument for project approval, while a negative NPV implied net loss. The size of the discount rate is a conflicted issue in environmental economics (Mullins et al., 2007). Following Marais and Wannenburgh (2008), we thus tested impact of a range of discount rates $(4 \%, 6 \%$ and $8 \%$ ) on the NPV.

We also tested whether a private landowner should pursue passive or active restoration if clearing costs are subsidized and he is only responsible for restoration costs.

\section{Results}

\section{Soil properties}

Total soil nitrogen $(\mathrm{N})$ levels in the Acacia thicket did not differ significantly before and after active restoration. Available $\mathrm{N}$ levels in the Acacia thicket increased after active restoration with significantly higher N levels in November 2008 than in October 2007 and February 2008. There was no significant difference between subtreatments; however, sown plots had significantly higher available $\mathrm{N}$ levels than unsown plots (interaction: $\chi_{1 \mathrm{df}}^{2}=9.1114, p<0.05$ ).

In the Eucalyptus plantation total $\mathrm{N}$ decreased significantly after active restoration (August 2008) $\left(\chi_{2 \mathrm{df}}^{2}=9.5091, p<0.01\right.$ ) and sown plots had significantly higher total $\mathrm{N}$ levels than unsown plots $\left(\chi_{1 \mathrm{df}}^{2}=5.1042, p<0.05\right)$ (Fig. 2$)$.

\section{Effects of restoration on vegetation parameters}

In the Kikuyu field evenness and diversity increased significantly after active restoration $\left(\chi_{1 \mathrm{df}}^{2}=7.9050, p<0.01, \chi_{1 \mathrm{df}}^{2}=8.2554\right.$, $p<0.01$, respectively) and diversity was significantly lower in sown plots compared to unsown plots $\left(\chi_{1 \mathrm{df}}^{2}=21.439, p<0.001\right)$. Sowing and the sub-treatment of herbicide application had a positive effect on evenness $\left(\chi_{2 \mathrm{df}}^{2}=8.167, p<0.05\right)$. Native cover and species richness showed no significant response to sowing or sub-treatments (Table 2).

At the Acacia site native cover decreased significantly $\left(\chi_{3 \mathrm{df}}^{2}=\right.$ $15.462, p<0.01)$ whereas diversity and evenness increased significantly after active restoration $\left(\chi_{1 \mathrm{df}}^{2}=6.332, p<0.05, \chi_{1 \mathrm{df}}^{2}=\right.$ $13.577, p<0.001$, respectively).

Species richness did not change significantly after active restoration. Diversity and evenness were significantly lower in sown plots compared to unsown plots $\left(\chi_{1 \mathrm{df}}^{2}=25.476, p<0.001\right.$, $\chi_{1 \mathrm{df}}^{2}=23.731, p<0.001$ ) (Table 2).

In the Eucalyptus plantation native cover showed significant higher levels in sown plots $\left(\chi_{1 \mathrm{df}}^{2}=4.622, p<0.05\right)$. Diversity increased significantly after active restoration $\left(\chi_{1 \mathrm{df}}^{2}=8.539\right.$, $p<0.01)$ and showed higher levels in sown plots than in unsown plots $\left(\chi_{1 \mathrm{df}}^{2}=7.069, p<0.05\right)$, whereas evenness did not differ significantly before and after active restoration and was not significantly affected by sowing or sub-treatments (Table 2 ).

Non-metrical multidimensional scaling analysis (NMDS) revealed no differences in species composition in sown plots compared to unsown plots in Kikuyu field and Acacia thicket. Species composition in the Eucalyptus plantations showed closer similarity among sown plots compared to unsown plots (Fig. 3). Similarity percentage analysis showed that the sown species Stoebe plumosa (27\%), P. capitatum (14\%) and L. coniferum (3\%) contributed significantly to observed differences.

\section{Cover of alien species}

At the Kikuyu site alien cover decreased significantly after active restoration with lower abundances of $P$. clandestinum in 2008, 2009 and $2010\left(\chi_{3 \mathrm{df}}^{2}=12.1203, p<0.01\right)$. Sowing of the competitive native species $L$. coniferum had no influence on Kikuyu cover. However, plots with the sub-treatment of follow-up herbicide application, showed significantly lower level of Kikuyu abundances than control plots $\left(\chi_{2 \mathrm{df}}^{2}=9.810, p<0.01\right.$ ) (Table 2 ).

Active restoration had a significant, negative effect on alien cover in the Acacia and Eucalyptus sites plantation $\left(\chi_{3 \mathrm{df}}^{2}=15.462\right.$, $p<0.01, \chi_{3 \mathrm{df}}^{2}=16.182, p<0.01$, respectively). However, alien cover did not differ significantly between sown and unsown plots or between sub-treatments on either of the sites (Table 2).

\section{Growth-form composition}

The growth form composition in the Kikuyu field was dominated by other shrubs in all three years in sown and unsown plots. In the Acacia thicket and Eucalyptus plantation herbaceous species (graminoids and forbs, respectively) dominated in all three years in sown and unsown plots (Fig. 4). In the Kikuyu field cover of proteoids increased significantly after active restoration in 2009 and $2010\left(\chi_{3 \mathrm{df}}^{2}=11.777, p<0.01\right)$. Moreover sub-treatment, sowing of $L$. coniferum, increased cover of proteoids significantly $\left(\chi_{2 \mathrm{df}}^{2}=\right.$ $9.115, p<0.05)$. Ericoid cover also was significantly higher in sown plots compared to unsown plots $\left(\chi_{1 \mathrm{df}}^{2}=8.111, p<0.01\right)$ (Table 2$)$.

At the Acacia site proteoid cover decreased significantly after active restoration in 2008, 2009 and $2010\left(\chi_{3 \mathrm{df}}^{2}=13.787, p<0.01\right)$. Sown plots had significant higher proteoid cover compared to unsown plots $\left(\chi_{1 \mathrm{df}}^{2}=8.694, p<0.01\right)$. Ericoid cover decreased significantly in 2008 but increased significantly two years after active restoration in $2010\left(\chi_{3 \mathrm{df}}^{2}=16.389, p<0.001\right)$ and showed significantly higher abundances in sown plots $\left(\chi_{1 \mathrm{df}}^{2}=14.518, p<0.001\right)$ (Table 2).

In the Eucalyptus plantation cover of proteoids and ericoids did not increase significantly after active restoration. Effects of splitplot treatments were positive with significantly higher abundances of ericoids and proteoids in sown plots $\left(\chi_{1 \mathrm{df}}^{2}=11.232, p<0.001\right.$, $\chi_{1 \mathrm{df}}^{2}=10.044, p<0.05$, respectively) (Table 2 ).

\section{Cost effectiveness of active versus passive restoration}

Clearing costs showed a large discrepancy between low and high Acacia and Eucalyptus densities (Table 3). When the income from ericoid and proteoid species over a period of 20 years is compared 
Table 2

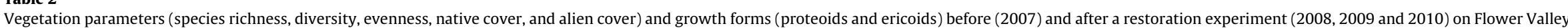

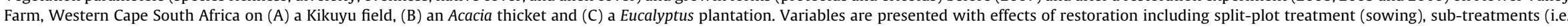

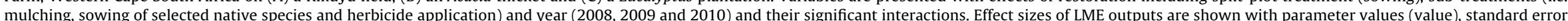
(se) and $p$-value. NA: data not available; ns: not significant.

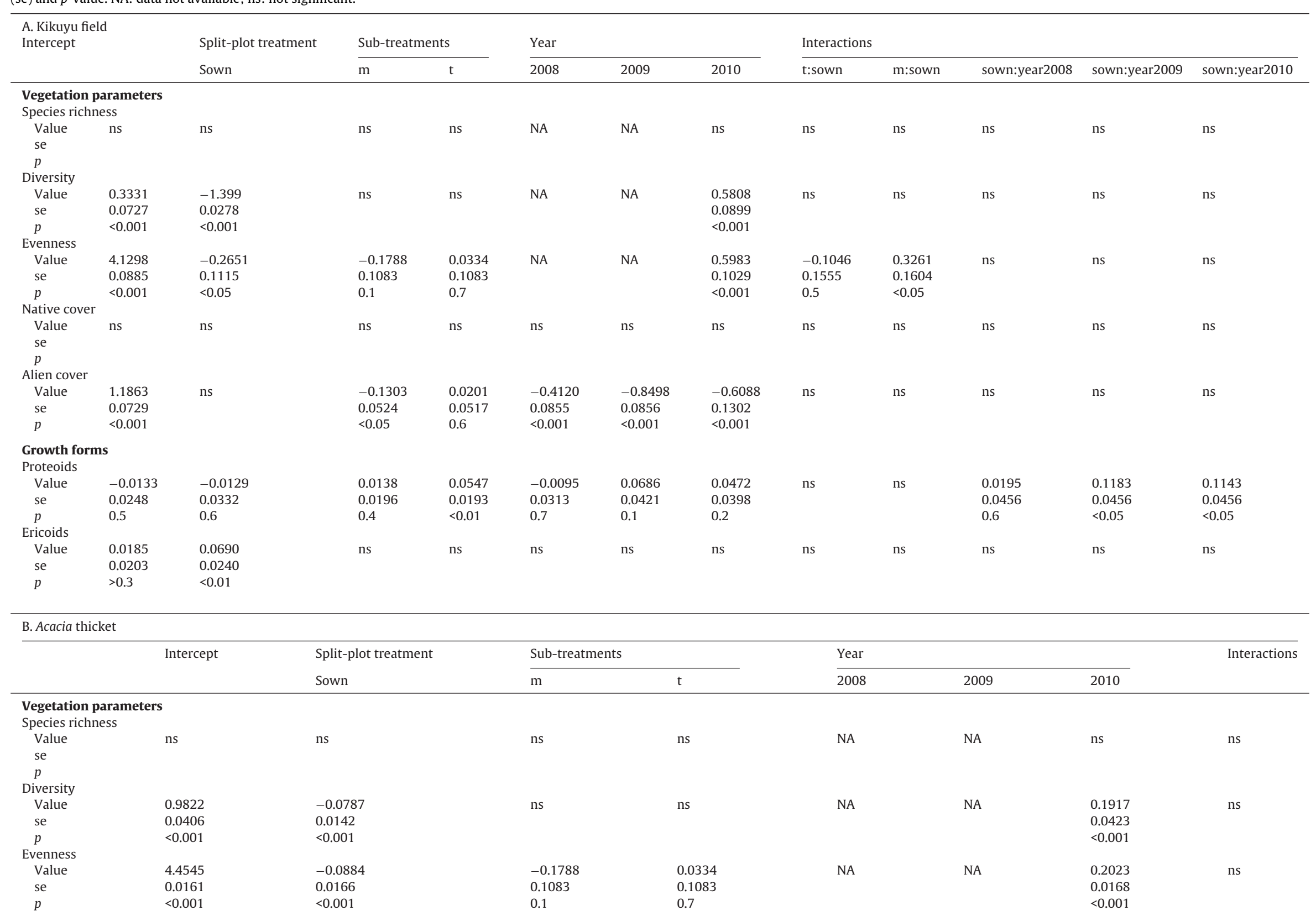


Table 2 (continued)

B. Acacia thicket

\begin{tabular}{|c|c|c|c|c|c|c|c|c|}
\hline & \multirow[t]{2}{*}{ Intercept } & \multirow{2}{*}{$\begin{array}{l}\text { Split-plot treatment } \\
\text { Sown }\end{array}$} & \multicolumn{2}{|c|}{ Sub-treatments } & \multicolumn{3}{|l|}{ Year } & \multirow[t]{2}{*}{ Interactions } \\
\hline & & & $\mathrm{m}$ & $\mathrm{t}$ & 2008 & 2009 & 2010 & \\
\hline \multicolumn{9}{|c|}{ Native cover } \\
\hline Value & 0.9475 & \multirow[t]{3}{*}{ ns } & \multirow[t]{3}{*}{ ns } & \multirow[t]{3}{*}{ ns } & -0.7027 & -0.2547 & -0.2223 & \multirow[t]{3}{*}{ ns } \\
\hline se & 0.0540 & & & & 0.0636 & 0.0522 & 0.0883 & \\
\hline$p$ & $<0.001$ & & & & $<0.001$ & $<0.001$ & $<0.05$ & \\
\hline \multicolumn{9}{|c|}{ Alien cover } \\
\hline Value & 0.8540 & \multirow[t]{3}{*}{ ns } & \multirow[t]{3}{*}{ ns } & \multirow[t]{3}{*}{ ns } & -0.7172 & -0.3783 & -0.7604 & \multirow[t]{3}{*}{ ns } \\
\hline se & 0.0624 & & & & 0.0805 & 0.0898 & 0.0724 & \\
\hline$p$ & $<0.001$ & & & & $<0.001$ & $<0.001$ & $<0.001$ & \\
\hline \multicolumn{9}{|c|}{ Growth forms } \\
\hline Proteoids & & & & & & & & \\
\hline Value & 0.3843 & 0.0702 & \multirow[t]{3}{*}{ ns } & \multirow[t]{3}{*}{ ns } & -0.3985 & -0.1750 & -0.2064 & \multirow[t]{3}{*}{ ns } \\
\hline se & 0.0441 & 0.0239 & & & 0.0460 & 0.0630 & 0.0569 & \\
\hline$p$ & $<0.001$ & $<0.01$ & & & $<0.001$ & $<0.01$ & $<0.001$ & \\
\hline Ericoids & & & & & & & & \\
\hline Value & 0.3425 & 0.0975 & ns & ns & -0.3693 & 0.0541 & 0.1550 & ns \\
\hline se & 0.0352 & 0.0253 & & & 0.0392 & 0.0452 & 0.0423 & \\
\hline$p$ & $<0.001$ & $<0.001$ & & & $<0.001$ & $>0.2$ & $<0.001$ & \\
\hline C. Eucalyp & & & & & & & & \\
\hline & Intercept & Split-plot treatment & Sub & & Year & & & Interactions \\
\hline & & Sown & $\mathrm{m}$ & $\mathrm{t}$ & 2008 & 2009 & 2010 & \\
\hline Vegetatio & & & & & & & & \\
\hline Species ri & & & & & & & & \\
\hline Value & ns & ns & ns & ns & NA & NA & ns & ns \\
\hline $\begin{array}{l}\text { se } \\
p\end{array}$ & & & & & & & & \\
\hline $\begin{array}{c}p \\
\text { Diversity }\end{array}$ & & & & & & & & \\
\hline $\begin{array}{c}\text { Drvestly } \\
\text { Value }\end{array}$ & 0.4734 & 0.0874 & $\mathrm{~ns}$ & ns & NA & $N A$ & 0.3029 & ns \\
\hline se & 0.0568 & 0.0327 & 115 & $11 \mathrm{~s}$ & NA & $\mathrm{NA}$ & 0.0468 & $11 \mathrm{~s}$ \\
\hline$p$ & $<0.001$ & $<0.01$ & & & & & $<0.001$ & \\
\hline Evenness & & & & & & & & \\
\hline Value & ns & ns & ns & ns & NA & NA & ns & ns \\
\hline se & & & & & & & & \\
\hline$p$ & & & & & & & & \\
\hline Native co & & & & & & & & \\
\hline Value & 0.8326 & 0.1017 & ns & ns & ns & ns & ns & $\mathrm{ns}$ \\
\hline se & 0.0461 & 0.0472 & & & & & & \\
\hline$p$ & $<0.001$ & $<0.05$ & & & & & & \\
\hline Alien cove & & & & & & & & \\
\hline Value & 1.0562 & ns & ns & ns & -0.8463 & -0.4940 & -0.7994 & ns \\
\hline se & 0.0555 & & & & 0.0687 & 0.0899 & 0.1045 & \\
\hline$p$ & $<0.001$ & & & & $<0.001$ & $<0.001$ & $<0.001$ & \\
\hline Growth $\mathrm{f}$ & & & & & & & & \\
\hline Proteoids & & & & & & & & \\
\hline Value & -0.0136 & 0.0390 & ns & ns & ns & ns & ns & ns \\
\hline se & 0.0104 & 0.0121 & & & & & & \\
\hline$p$ & 0.1 & $<0.01$ & & & & & & \\
\hline Ericoids & & & & & & & & \\
\hline Value & -0.0281 & 0.1318 & ns & ns & ns & ns & ns & ns \\
\hline se & 0.0326 & 0.0386 & & & & & & \\
\hline$p$ & 0.3 & $<0.001$ & & & & & & \\
\hline
\end{tabular}




\section{a Acacia thicket}
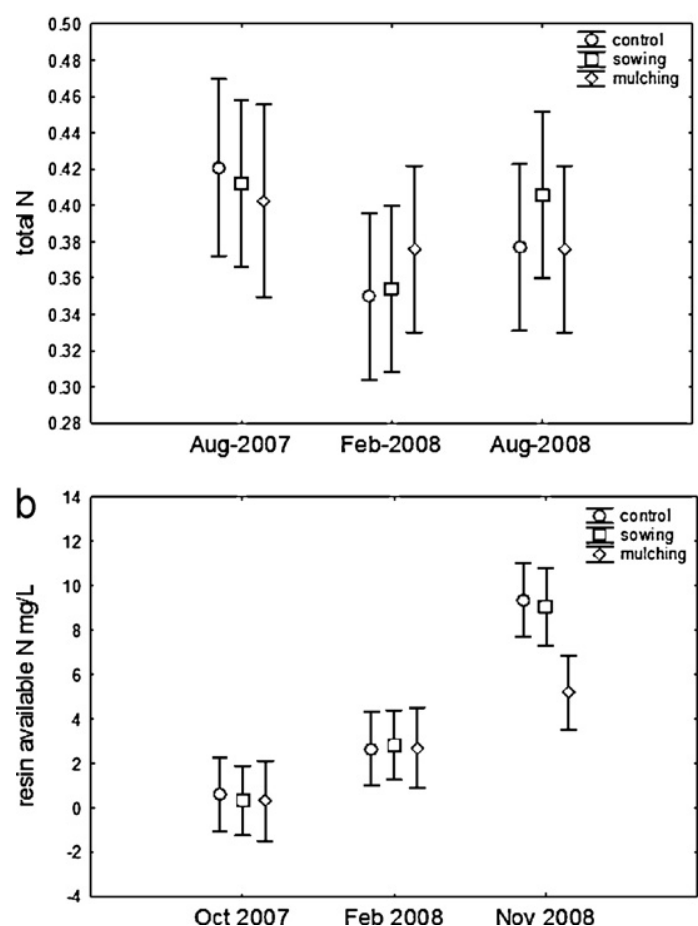

Eucalyptus plantation
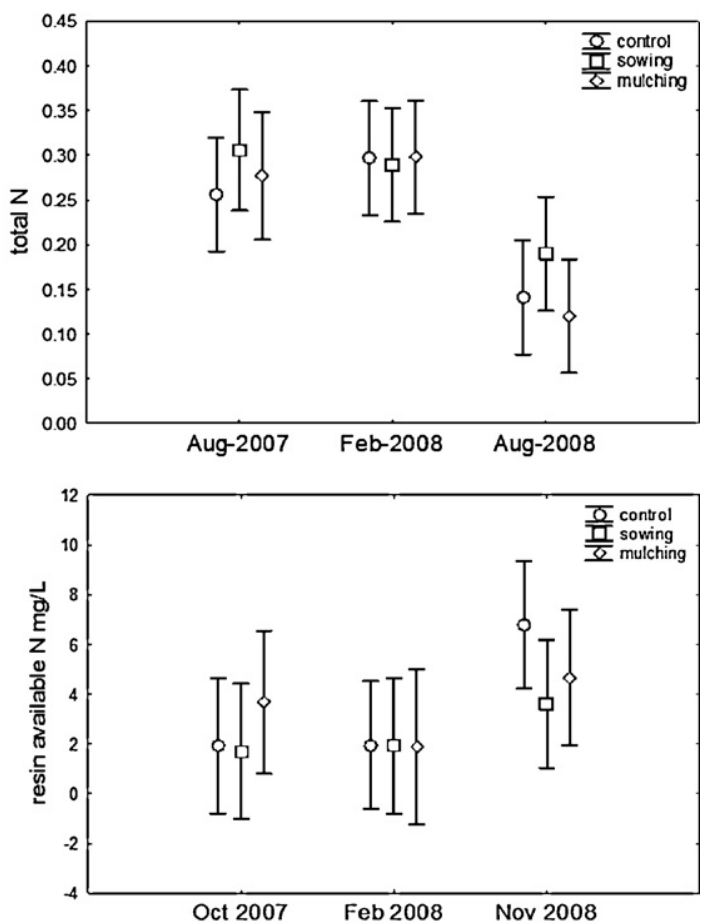

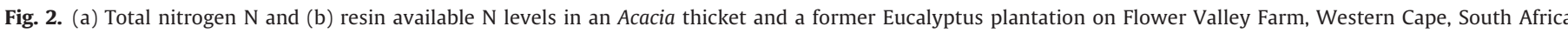

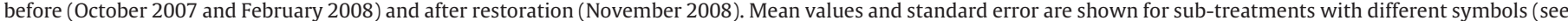

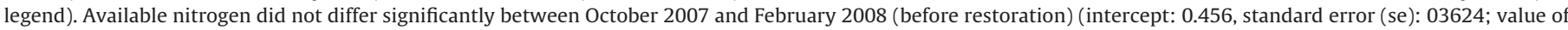

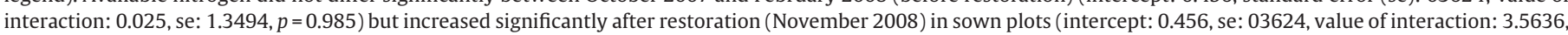

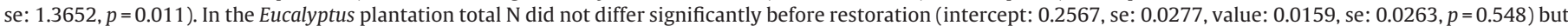

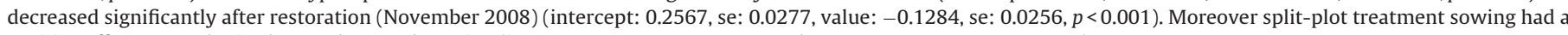
positive effect on total $\mathrm{N}$ in the eucalyptus plantation (intercept: 0.2567 , se: 0.0277 , value: 0.0441 , se: $0.0196, p<0.05$ ).

to the costs of clearing and restoring an Acacia thicket or Eucalyptus plantation, active restoration is distinctly favoured over passive restoration, with one exception: if a high discount rate is assumed for the restoration of a Eucalyptus plantation, future benefits lose value too fast to offset the additional costs of active restoration. In contrast, the higher income from active restoration of a Kikuyu field does not sufficiently offset its costs to render it preferable to passive restoration. Neither passive nor active restoration practices in any of the highly invaded sites produces a positive return (i.e. a NPV >0). However, active restoration of low density Acacia thickets can be justified on financial terms, suggesting that these areas should be prioritized (Fig. 5).

If clearing costs are subsidized the results show that in a Kikuyu field, passive restoration will provide a positive and higher return than active restoration. Passive and active restoration of an Acacia thicket will both provide a positive NPV, but active restoration will allow more than double the return. Returns from passive and active restoration of a Eucalyptus plantation depend on the discount rate assumed, with the results suggesting that at lower discount rates active restoration provides a more favourable outcome (Fig. 6).

\section{Discussion}

Effectiveness of active restoration activities in restoring diverse and functional ecosystems

Active restoration after removal of invasive alien species revealed mixed results. Increases in diversity and evenness after restoration in all three sites confirm that the active restoration was

Table 3

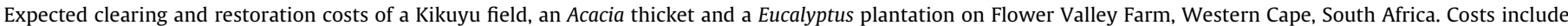

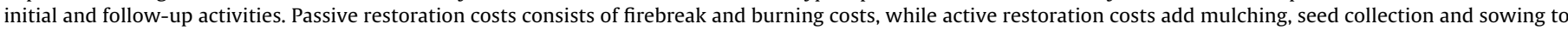
the total ( 1 ZAR=0.13US\$; 06 March 2012).

\begin{tabular}{|c|c|c|c|c|c|}
\hline \multirow[t]{3}{*}{ Invaded sites } & \multicolumn{5}{|c|}{ Active restoration per ha } \\
\hline & \multicolumn{2}{|c|}{ Passive restoration per ha } & \multirow{2}{*}{$\begin{array}{l}\text { Total passive } \\
\text { restoration }\end{array}$} & \multirow{2}{*}{$\begin{array}{l}\text { Mulching and } \\
\text { sowing }\end{array}$} & \multirow{2}{*}{$\begin{array}{l}\text { Total active } \\
\text { restoration per } \\
\text { ha }\end{array}$} \\
\hline & Clearing & $\begin{array}{l}\text { Fire breaks and } \\
\text { burning }\end{array}$ & & & \\
\hline Kikuyu field & $1080 \mathrm{ZAR}$ & 498 ZAR & $1578 \mathrm{ZAR}$ & 980 ZAR & $2558 \mathrm{ZAR}$ \\
\hline Acacia thicket (low density) & 266 ZAR & 498 ZAR & 764 ZAR & $980 \mathrm{ZAR}$ & 1744 ZAR \\
\hline Acacia thicket (high density) & $3301 \mathrm{ZAR}$ & 498 ZAR & 3799 ZAR & $980 \mathrm{ZAR}$ & $4779 \mathrm{ZAR}$ \\
\hline Eucalyptus plantation (low density) & $1155 \mathrm{ZAR}$ & 910 ZAR & 2065 ZAR & 980 ZAR & 3045 ZAR \\
\hline Eucalyptus plantation (high density) & $3201 \mathrm{ZAR}$ & 910 ZAR & 4111 ZAR & $980 \mathrm{ZAR}$ & 5091 ZAR \\
\hline
\end{tabular}



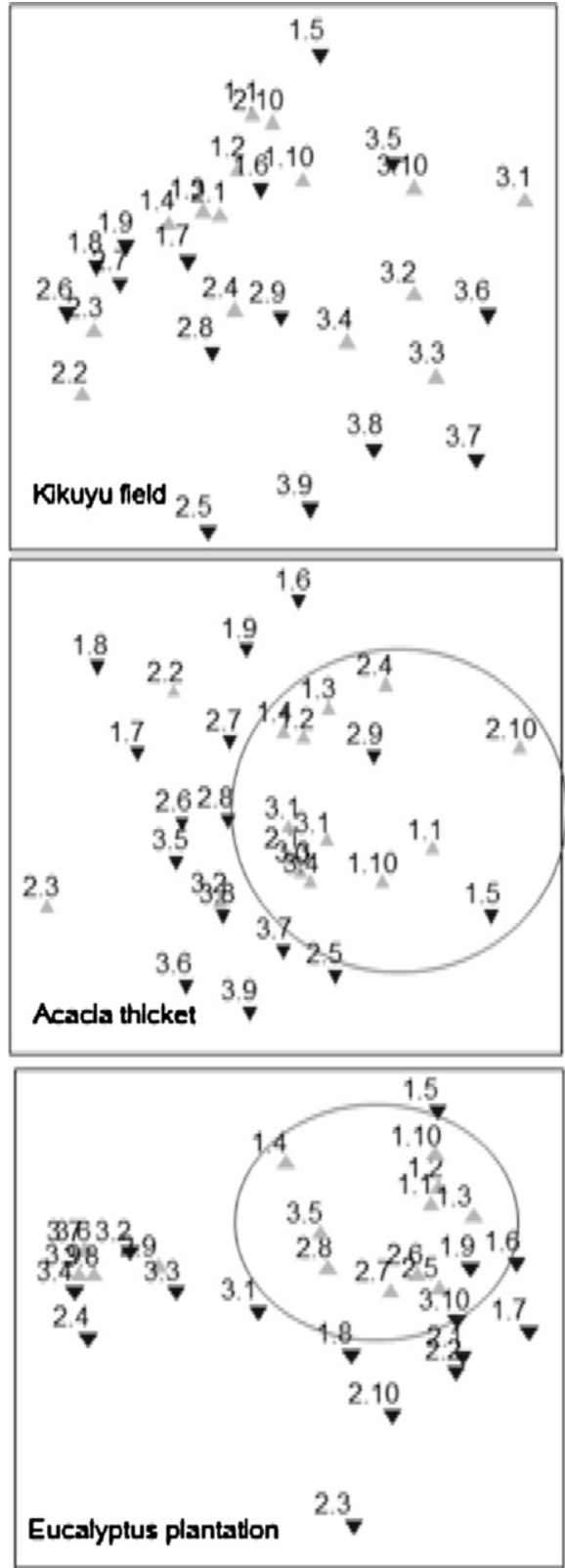

sown

unsown

Fig. 3. Ordination analysis (non metric multi dimensional scaling (NMDS)) of vegetation plots grouped by split-plot treatment (sown and unsown plots) after restoration of a Kikuyu field, an Acacia thicket, and a former Eucalyptus plantation on Flower Valley Farm, Western Cape, South Africa. Species abundances were used for similarity testing (Bray-Curtis diversity index) after square root transformation. NMDS was running 50 iterations with a minimum stress value of 0.01 . Grey and black triangles indicate the sown and unsown plots, respectively.

successful. However, looking at the effects of split-plot treatments and sub-treatments separately shows that the split-plot treatment (sowing) had no significant effect on native cover, species richness, diversity or evenness in Acacia thicket and Kikuyu field, but only for the Eucalyptus plantation. This implies that the native ecosystem was still resilient enough (except in the eucalypt stand) for autogenic recovery to occur, indicating that although structural biotic and abiotic changes had occurred (Gaertner et al., 2011), the key ecosystem processes had not yet been seriously compromised.

Treatments aimed at reducing levels of total soil nitrogen in the Acacia thicket were unsuccessful, and levels of available $\mathrm{N}$ increased after restoration with no significant effects of sub-treatments. The high levels of total $\mathrm{N}$ after clearing of invasive Acacia species in our
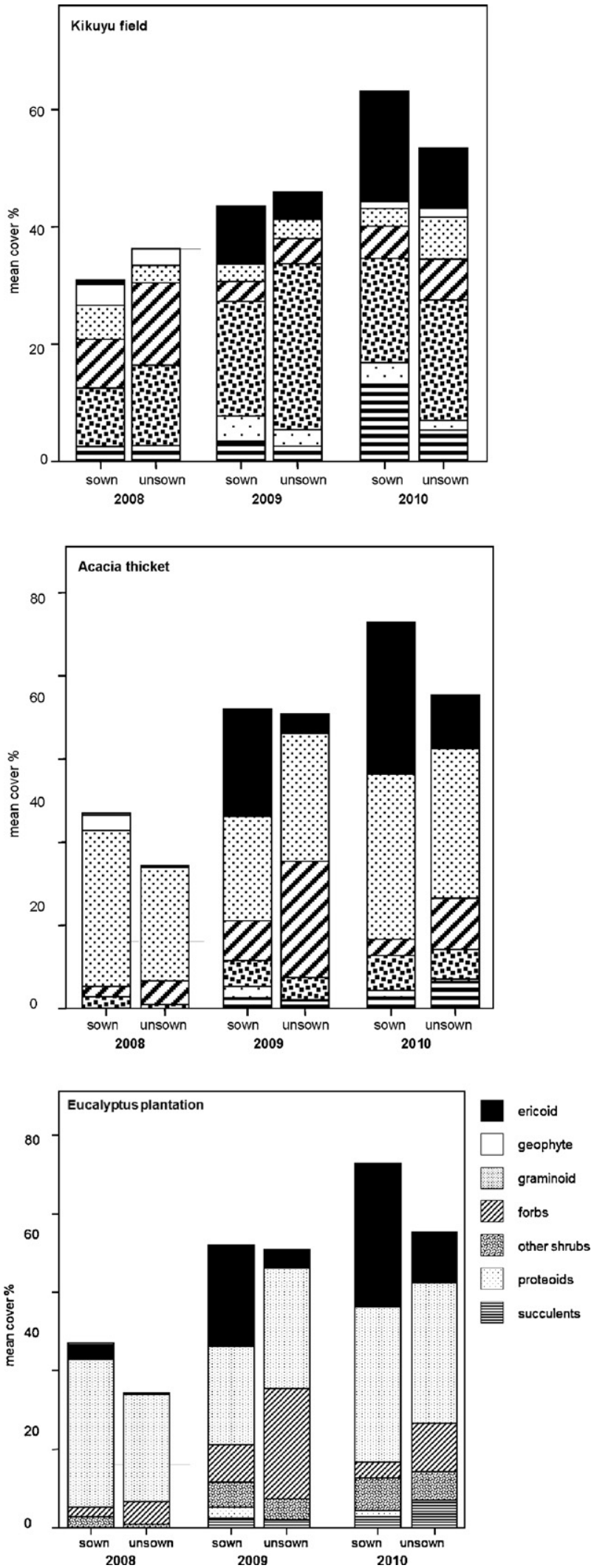

Fig. 4. Growth form composition in a Kikuyu field, Acacia thicket and a former Eucalyptus plantation in sown and unsown plots following a restoration experiment in Flower Valley Farm, Western Cape, South Africa. 


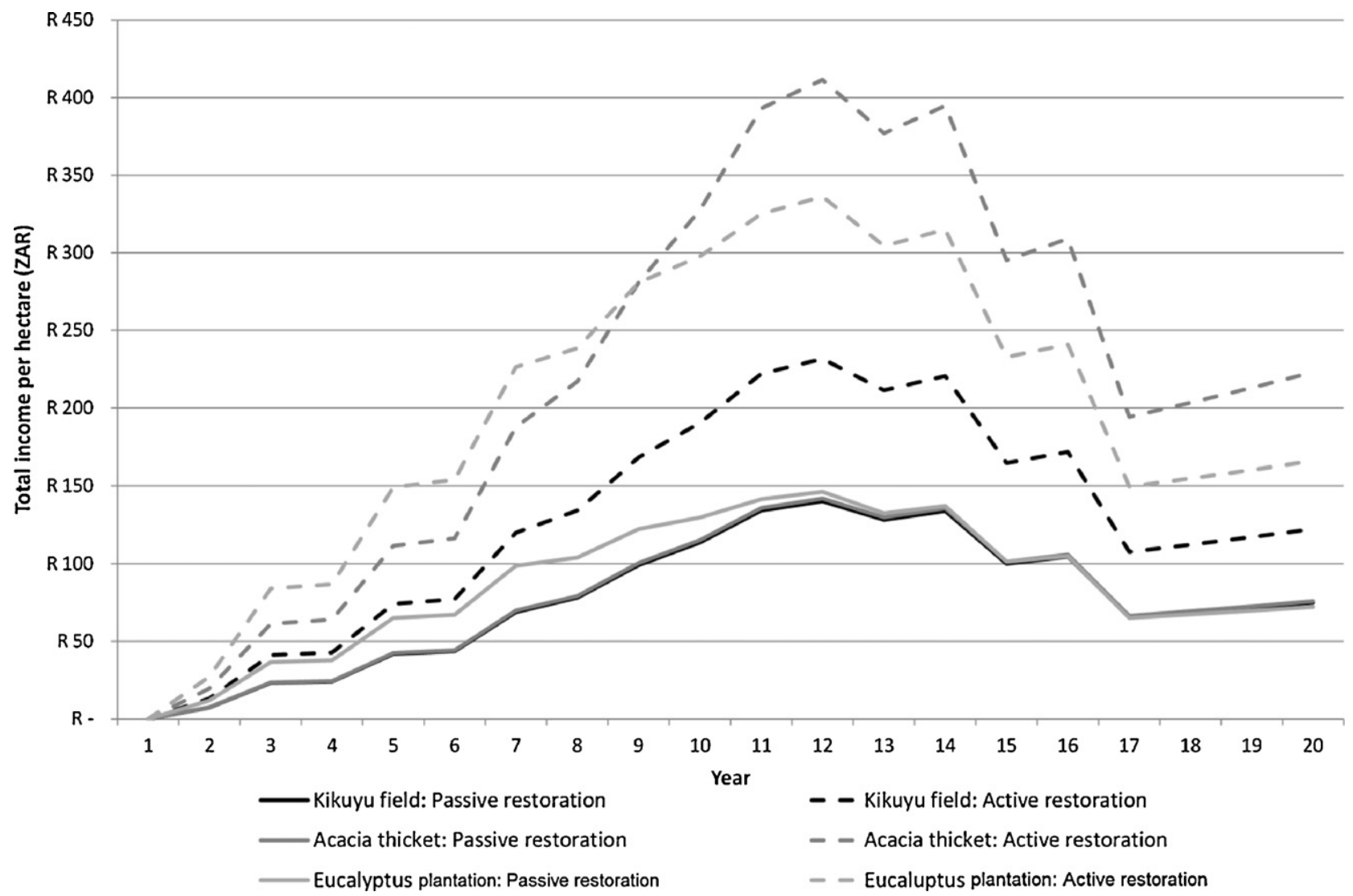

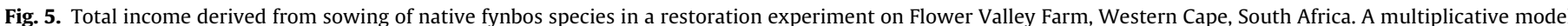
was used to estimate the income derived from proteoid and ericoid species on passively or actively restored land over 20 years.

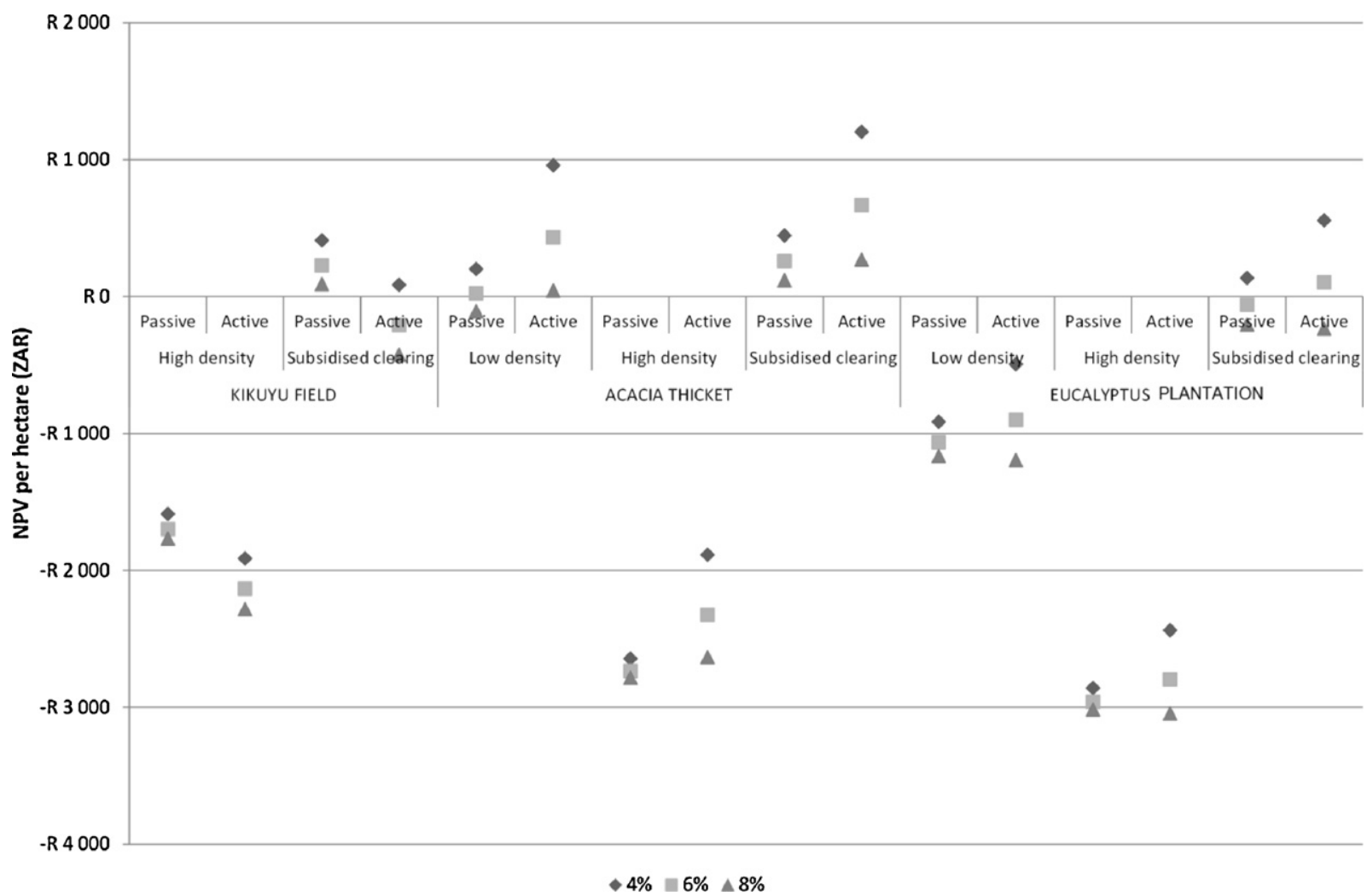

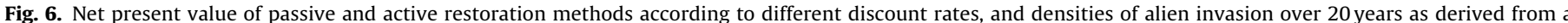
restoration experiment on Flower Valley Farm, Western Cape, South Africa. 
study agree with the findings of work in Portuguese dune ecosystems: Marchante et al. (2009) showed that it takes several years for soil nutrient levels to return to pre-invasion levels after clearing of Acacia species. High levels of total $\mathrm{N}$ after restoration could also be ascribed to fire; increased total nitrogen levels observed in the immediate post-fire phase are in agreement with other studies (Stock and Lewis, 1986; Musil and Midgley, 1990). It should, however, be noted that Musil and Midgley (1990) found the impact of fire on the soil chemical status of fynbos vegetation to be less than that of Acacia infestation, and mainly transient.

Higher levels of available $\mathrm{N}$ following restoration could be due to the relatively low available $\mathrm{N}$ levels under Acacia (before restoration); Acacia species are characterized by efficient nutrient uptake and can use more of the available nitrogen in the soil than native species (Peperkorn et al., 2005; Werner et al., 2010). It has also been shown that enhanced levels of plant available $\mathrm{N}$ can lead to higher nutrient uptake, both by native plant species and by Acacia species (Hellmann et al., 2011). The fact that adding carbon-rich mulch did not reduce soil $\mathrm{N}$ levels could be because soil microbes were not C-limited or that not enough C was added (Perry et al., 2010).

It has been suggested that the persistence of high soil nutrient levels may hamper re-introduction of native communities for a long period (Marchante et al., 2008; Gaertner et al., 2011). In our study, native species germinated irrespective of whether seeds were actively sown or not (i.e. regeneration from the soil seed bank), despite the elevated available soil $\mathrm{N}$ levels. This supports the findings of Musil (1993) who showed that higher soil nutrient levels produced by acacia invasion do not hamper fynbos seedling growth. However, the growth-form composition shows that without the introduction of native species, native grasses, forbs and other shrubs would have dominated, whereas proteoids and ericoids, the major fynbos growth forms, would have been under-represented. The dominance of fast-growing, mostly herbaceous, species after alien clearing (secondary invasion) is a common problem especially if abiotic conditions have been changed in favour of competitive species (Richardson et al., 2000; Marchante et al., 2004; Vinton and Goergen, 2006). The removal of overstorey species (e.g. proteoids and ericoids) can significantly change vegetation structure, which may compromise various ecosystem processes in the long-term (Holmes et al., 2000). Establishment representation of growth forms approximating that of reference communities is therefore important (Holmes and Richardson, 1999).

It has been argued that re-invasion of natural ecosystems after invasive species control can best be minimized in the long-term if native plant species can re-establish rapidly and compete for resources with the managed invader and/or other invasive plants (Buckley et al., 2007; Reid et al., 2009). Vranjic et al. (2012) showed that increasing the abundance of native species at managed sites through re-vegetation reduces the likelihood of Bitou bush ( $C$. monilifera) re-colonization. However, our hypothesis that introduced native species would have the capacity to outcompete alien invaders could not be confirmed. This can be ascribed to the rapid growth and high competitiveness of alien species at all three sites (Schooler et al., 2010; Morris et al., 2011). Our results highlight that follow-up clearing is crucial and the only effective means of controlling alien regrowth.

\section{Financial incentives for restoration after alien invasion}

Species were not only introduced for ecological reasons but also to investigate whether adding species that are popular in the fynbos flower market could provide sufficient financial incentive to restore invaded sites. The financial analysis illustrates that total income from active restoration consistently outweighs income from passive restoration, but that the associated costs are not always justified. The density (i.e. duration) of invasion is an important determinant of whether alien clearing and restoration results in a net gain or a net loss when land is restored to a state that enables sustainable harvesting. It must be noted that our cost-benefit analysis did not include pure "biodiversity benefits" (i.e. tourism value) or ecosystem service benefits (i.e. clean drinking water) which could additionally be calculated in favour of re-establishing native ecosystems.

In summary, the findings of the ecological and financial analysis suggest that active restoration can be partly effective and financially feasible when compared to passive restoration. An important finding is that density of invasion is the key determinant influencing whether clearing of invasive plants and restoration results in a net gain or loss. Holmes et al. (2000) state that intensity of restoration intervention required is proportional to the duration (i.e. density) of invasion and therefore recommend that invaded sites should be cleared as soon as possible. Our results support this finding. Invasion will eventually trigger alterations of biotic and abiotic ecosystem components. A densely invaded area will therefore require major management input and financial resources; active restoration should thus only be undertaken once realistic goals have been established. Apart from financial considerations, the feasibility of active restoration will depend on the location of the area. If the area is located in a region of high conservation priority, restoration to at least a structural representative natural state should be attempted. If the area is surrounded by transformed habitat (e.g. agricultural lands) ecological restoration to a target reference ecosystem (focusing on biodiversity) may not be feasible or justifiable. In such cases, rehabilitation (i.e. restoring ecosystem processes and functions) will be more appropriate.

\section{Acknowledgements}

We thank Patricia Holmes for helpful discussions regarding experiment implementation, for her enthusiastic support throughout the project, and for her comments on the manuscript. Financial support was provided by the Flower Valley Conservation Trust and the Agulhas Biodiversity Initiative. We acknowledge support from the DST-NRF Centre of Excellence for Invasion Biology (MG, DMR), the National Research Foundation (DMR) and the Hans Sigrist Foundation (DMR). We also thank Dr Martin de Wit at the School of Public Leadership (Stellenbosch University), Mr Albert van der Merwe at the Department of Economics (Stellenbosch University), and ASSET Research for guidance regarding the financial analysis. Thanks are also extended to Roger Bailey at Flower Valley Farm for making data available. Henning Nottebrock acknowledges support from the German Research Foundation DFG (grant SCHU 2259/3-1).

\section{Appendix A. Supplementary data}

Supplementary data associated with this article can be found, in the online version, at http://dx.doi.org/ 10.1016/j.ppees.2012.05.001.

\section{References}

Aronson, J., Blignaut, J.N., Milton, S.J., Le Maitre, D., Esler, K.J., Limouzin, A., Fontaine, C., De Wit, M.P., Mugido, W., Prinsloo, P., Van Der Elst, L., Lederer, N., 2010. Are socioeconomic benefits of restoration adequately quantified? A meta-analysis of recent papers (2000-2008) in Restoration Ecology and 12 other scientific journals. Restor. Ecol. 18, 143-154.

Bailey, R., Privett, S.D.J., Brown, D.E., 2008. Resource Base Assessment of Wild Fynbos Harvestable Plants for SANPARKS: Soetanys Farm. Flower Valley Conservation Trust.

Bakker, J.D., Wilson, S.D., 2004. Using ecological restoration to constrain biological invasion. J. Appl. Ecol. 41, 1058-1064. 
Benayas, J.M.R., Newton, A.C., Diaz, A., Bullock, J.M., 2009. Enhancement of biodiversity and ecosystem services by ecological restoration: a meta-analysis. Science $325,1121-1124$.

Blumenthal, D.M., Jordan, N.R., Russele, M.P., 2003. Soil carbon addition controls weeds and facilitates prairie restoration. Ecol. Appl. 13, 605-615.

Buckley, Y., 2008. The role of research for integrated management of invasive species, invaded landscapes and communities. J. Appl. Ecol. 45, 397-402.

Buckley, Y.M., Bolker, B.M., Rees, M., 2007. Disturbance, invasion and re-invasion: managing the weed-shaped hole in disturbed ecosystems. Ecol. Lett. 10, 809-817.

Clarke, K.R., Warwick, R.M., 2001. Change in Marine Communities: An Approach to Statistical Analysis and Interpretation. PRIMER-E Ltd., Plymouth.

Conradie, B., Knoesen, H., 2009. A survey of cultivation and wildflower harvesting of fynbos flowers in South Africa. PPSA Nuusbrief.

Cox, R.D., Allen, E.B., 2008. Stability of exotic annual grasses following restoration efforts in southern California coastal sage scrub. J. Appl. Ecol. 45, 495-504.

Crawley, M.J., 2007. The R Book. Wiley, Chichester.

Department of Agriculture, Forestry and Fisheries, 2011. Guide to Machinery Costs, August.

D’Antonio, C., Meyerson, L.A., 2002. Exotic plant species as problems and solutions in ecological restoration: a synthesis. Restor. Ecol. 10, 703-713.

Ehrenfeld, J.G., 2003. Effects of exotic plant invasions on soil nutrient cycling processes. Ecosystems 6, 503-523.

Esler, K.J., Holmes, P.M., Richardson, D.M., Witkowski, E.T.F., 2008. Riparian vegetation management in landscapes invaded by alien plants: insights from South Africa. S. Afr. J. Bot. 74, 397-400.

Forsyth, G.G., Richardson, D.M., Brown, P.J., Van Wilgen, B.W., 2004. A rapid assessment of the invasive status of Eucalyptus species in two South African provinces. S. Afr. J. Sci. 100, 75-77.

Gaertner, M., Richardson, D.M., Privett, S.D.J., 2011. Effects of alien plants on ecosystem structure and functioning and implications for restoration: insights from three degraded sites in South African fynbos. Environ. Manage. 48, 57-69.

Gaertner, M., Holmes, P.M., Richardson, D.M., 2012. Biological invasions, resilience and restoration. In: Andel, J., Aronson, J. (Eds.), Restoration Ecology: The New Frontier. Wiley-Blackwell, Oxford, pp. 265-280.

Galatowitsch, S., Richardson, D.M., 2005. Riparian scrub recovery after clearing of invasive alien trees in headwater streams of the Western Cape, South Africa. Biol. Conserv. 122, 509-521.

Goldstein, J.H., Pejchar, L., Daily, G.C., 2008. Using return-on-investment to guide restoration: a case study from Hawaii. Conserv. Lett. 1, 236-243.

Hellmann, C., Sutter, R., Rascher, K.G., Máguas, C., Correia, O., Werner, C., 2011. Impact of an exotic $\mathrm{N}_{2}$-fixing Acacia on composition and $\mathrm{N}$ status of a native Mediterranean community. Acta Oecol. 37, 43-50.

Henderson, L., 2007. Invasive, naturalized and casual alien plants in southern Africa: a summary based on the Southern African Plant Invaders Atlas (SAPIA). Bothalia 37, 215-248.

Heydenrych, B.J., 1999. An investigation of the land-use practices on the Agulhas Plain (South Africa), with emphasis on socio-economic and conservation issues. PhD Thesis. University of Cape Town.

Holl, K.D., Howarth, R.B., 2000. Paying for restoration. Restor. Ecol. 8, 260-267.

Holmes, P.M., 2001. Shrubland restoration following woody alien invasion and mining: effects of topsoil depth, seed source, and fertilizer addition. Restor. Ecol. 9, 71-84.

Holmes, P.M., 2002. Depth distribution and composition of seed-banks in alieninvaded and uninvaded fynbos vegetation. Austral Ecol. 27, 110-120.

Holmes, P.M., 2008. Optimal ground preparation treatments for restoring lowland Sand Fynbos vegetation on old fields. S. Afr. J. Bot. 74, 33-40.

Holmes, P.M., Cowling, R.M., 1997. Diversity, composition and guild structure relationships between soil-stored seed banks and mature vegetation in alien plant-invaded South African fynbos shrubland. Plant Ecol. 133, 107-122.

Holmes, P.M., Richardson, D.M., 1999. Protocols for the restoration based on recruitment dynamics, community structure and ecosystem function: perspectives from South African fynbos. Restor. Ecol. 7, 215-230.

Holmes, P.M., Richardson, D.M., Van Wilgen, B.W., Gelderblom, C., 2000. Recovery of South African fynbos vegetation following alien woody plant clearing and fire: implications for restoration. Austral Ecol. 25, 631-639.

Le Maitre, D.C., Gaertner, M., Marchante, E., Ens, E.-J., Holmes, P.M., Pauchard, A., O'Farrell, P., Rogers, A.M., Blanchard, R., Blignaut, J., Richardson, D.M., 2011. Impacts of invasive Australian acacias: implications for management and restoration. Divers. Distrib. 17, 1015-1029.

Lindsay, E.A., French, K., 2005. Litterfall and nitrogen cycling following invasion by Chrysanthemoides monilifera ssp. rotundata in coastal Australia. J. Appl. Ecol. 42, 556-566.

Loo, S.E., McNally, R., O’Dowd, D.J., Lake, P.S., 2009. Secondary invasions: implications of riparian restoration for in-stream invasion by an aquatic grass. Restor. Ecol. 17, 378-385.

Marais, C., Wannenburgh, A.M., 2008. Restoration of water resources (natural capital) through the clearing of invasive alien plants from riparian areas in South Africa - costs and water benefits. S. Afr. J. Bot. 74, 526-537.

Marchante, H.S., Marchante, E.M., Buscardo, E., Maia, J., Freitas, H., 2004. Recovery potential of dune ecosystems invaded by an exotic Acacia species (Acacia longifolia). Weed Technol. 18, 1427-1433.

Marchante, E., Kjoller, A., Struwe, S., Freitas, H., 2008. Short- and long-term impacts of Acacia longifolia invasion on the belowground processes of a Mediterranean coastal dune ecosystem. Appl. Soil Ecol. 40, 210-217.
Marchante, E., Kjoller, A., Struwe, S., Freitas, H., 2009. Soil recovery after removal of the $\mathrm{N}_{2}$-fixing invasive Acacia longifolia: consequences for ecosystem restoration. Biol. Invas. 11, 813-823.

Milton, S.J., Dean, W.R.J., Richardson, D.M., 2003. Economic incentives for restoring natural capital in southern African rangelands. Front. Ecol. Environ. 1, 247-254.

Morghan, K.J.R., Seastedt, T.R., 1999. Effects of soil nitrogen reduction on non-native plants in restored grasslands. Restor. Ecol. 7, 51-55.

Morris, T.L., Esler, K.J., Barger, N.N., Jacobs, S.M., Cramer, M.D., 2011. Ecophysiological traits associated with the competitive ability of invasive Australian acacias. Divers. Distrib. 17, 898-910.

Mullins, D., Mosaka, D.D., Green, A.B., Downing, R., Mapekula, P.G., 2007. A Manual for Cost Benefit Analysis in South Africa with Specific Reference to Water Resource Development. WRC Report No. TT 305/07, second edition.

Musil, C.F., 1993. Effect of invasive Australian Acacias on the regeneration, growth and nutrient chemistry of South-African lowland fynbos. J. Appl. Ecol. 30 361-372.

Musil, C.F., Midgley, G.F., 1990. The relative impact of invasive Australian Acacias, fire and season on the soil chemical status of a sand plain lowland fynbos community. S. Afr. J. Bot. 56, 419-427.

Peperkorn, R., Werner, C., Beyschlag, W., 2005. Phenotypic plasticity of an invasive acacia versus two native Mediterranean species. Funct. Plant Biol. 32 933-944.

Perry, L.G., Blumenthal, D.M., Monaco, T.A., Paschke, M.W., Redente, E.F., 2010 Immobilizing nitrogen to control plant invasion. Oecologia 163, 13-24.

Pinheiro, J., Bates, D., Debroy, S., Sarkar, D., 2007. nlme: Linear and Nonlinear Mixed Effects Models. R Package Version 3.1-89.

Posada, J.M., Aide, T.M., Cavelier, J., 2000. Cattle and weedy shrubs as restoration tools of tropical montane rainforest. Restor. Ecol. 8, 370-379.

Prober, S.M., Thiele, K.R., Lunt, I.D., Koen, T.B., 2005. Restoring ecological function in temperate grassy woodlands: manipulating soil nutrients, exotic annuals and native perennial grasses through carbon supplements and spring burns. J. Appl. Ecol. 42, 1073-1085.

Rebelo, A.G., Boucher, C., Helme, N., Mucina, L., Rutherford, M.C., 2006. Fynbos biome. In: Mucina, L., Rutherford, M.C. (Eds.), The Vegetation of South Africa, Lesotho and Swaziland. South African National Biodiversity Institute, Pretoria, pp. 52-219.

Reid, A.M., Morin, L., Downey, P.O., French, K., Virtue, J.G., 2009. Does invasive plant management aid the restoration of natural ecosystems? Biol. Conserv. $142,2342-2349$

Richardson, D.M., Kluge, R.L., 2008. Seed banks of invasive Australian Acacia species in South Africa: role in invasiveness and options for management. Perspect. Plant. Ecol. Evol. Syst. 10, 161-177.

Richardson, D.M., Van Wilgen, B.W., 2004. Invasive alien plants in South Africa: how well do we understand the ecological impacts? S. Afr. J. Sci. 100, 45-52.

Richardson, D.M., Bond, W.J., Dean, W.R.J., Higgins, S.I., Midgley, G.F., Milton, S.J., Powrie, L., Rutherford, M.C., Samways, M.J., Schulze, R.E., 2000. Invasive alien organisms and global change: a South African Perspective. In: Mooney, H.A. Hobbs, R.J. (Eds.), Invasive Species in a Changing World. Island Press, Washing ton, DC, pp. 303-349.

Rouget, M., Richardson, D.M., Cowling, R.M., Lloyd, J.W., Lombard, A.T., 2003. Current patterns of habitat transformation and future threats to biodiversity in terrestrial ecosystems of the Cape Floristic Region, South Africa. Biol. Conserv. 112, 63-85.

Roura-Pascual, N., Richardson, D.M., Krug, R.M., Brown, A., Chapman, R.A., Forsyth G.G., Le Maitre, D.C., Robertson, M.P., Stafford, L., Van Wilgen, B.W., Wannenburgh, A. Wessels, N., 2009. Ecology and management of alien plant invasions in South African fynbos: accommodating key complexities in objective decision making. Biol. Conserv. 142, 1595-1604.

Ruwanza, S., 2009. Soil nitrogen and phosphorus depletion as a means of restoring degraded lowland fynbos ecosystems invaded by alien grasses. MSc Thesis. Stellenbosch University, Stellenbosch.

Schooler, S.S., Cook, T., Prichard, G., Yeates, A.G., 2010. Disturbance-mediated competition: the interacting roles of inundation regime and mechanical and herbicidal control in determining native and invasive plant abundance. Biol. Invas. 12, 3289-3298.

Scott, A., Martens, C., Marais, C., Palmer, G., Kabot, L., Middelman, M., Scott, M. Holmes, P.M., Saunders, R., Privett, S.D.J., Carinus, T., Gerber, F., Blomerus, L., de Ponte Machado, M., 2004. An Introduction to Sustainable Harvesting of Some Commercially Utilised Indigenous Plant Species in the Cape Floristic Region. Critical Ecosystems Partnership Fund, Cape Town.

Stock, W.D., Lewis, O.A.M., 1986. Soil nitrogen and the role of fire as a mineralizing agent in South African coastal fynbos ecosystems. J. Ecol. 74, 317-328.

Suding, K.N., LeJeune, K.D., Seastedt, T.R., 2004. Competitive impacts and responses of an invasive weed: dependencies on nitrogen and phosphorus availability. Oecologia 141, 526-535.

TradeMap, 2012. List of importing markets for the product exported by South Africa in 2010. Product: 0603 Cut flowers and flower buds for bouquets, fresh or dried. Available online: http://www.trademap.org

Venables, W.N., Ripley, B.D., 2002. Modern Applied Statistics with S. Springer, New York.

Vince, G., 2011. Conservation ecology. Embracing invasives. Science 331, 1383-1384.

Vinton, M.A., Goergen, E.M., 2006. Plant-soil feedbacks contribute to the persistence of Bromus inermis in tallgrass prairie. Ecosystems 9, 967-976. 
Vranjic, J.A., Morin, L., Reid, A.M., Groves, R.H., 2012. Integrating revegetation with management methods to rehabilitate coastal vegetation invaded by Bitou bush (Chrysanthemoides monilifera ssp. rotundata) in Australia. Austral Ecol. 37, 78-89.

Werner, C., Zumkier, U., Beyschlag, W., Maguas, C., 2010. High competitiveness of a resource demanding invasive acacia under low resource supply. Plant Ecol. 206, $83-96$.

Wilson, J.R.U., Gairifo, C., Gibson, M.R., Arianoutsou, M., Bakar, B.B., Baret, S., CelestiGrapow, L., DiTomaso, J.M., Dufour-Dror, J.-M., Kueffer, C., Kull, C.A., Hoffmann,
J.H., Impson, F.A.C., Loope, L.L., Marchante, E., Marchante, H., Moore, J.L., Murphy, D.J., Tassin, J., Witt, A., Zenni, R.D., Richardson, D.M., 2011. Risk assessment, eradication, and biological control: global efforts to limit Australian acacia invasions. Divers. Distrib. 17, 1030-1046.

Yelenik, S.G., Stock, W.D., Richardson, D.M., 2004. Ecosystem level impacts of invasive Acacia saligna in the South African fynbos. Restor. Ecol. 12, 44-51.

Zavaleta, E.S., Hobbs, R.J., Mooney, H.A., 2001. Viewing invasive species removal in a whole-ecosystem context. Trends Ecol. Evol. 16, 454-459. 